\title{
La recepción de Lucie Delarue-Mardrus en la Edad de Plata: tensiones en torno a autoría y feminidad
}

\author{
Isabel CLÚA \\ Universidad de Sevilla \\ iclua@us.es \\ https://orcid.org/0000-0001-8577-4686
}

\begin{abstract}
Resumen
El propósito de este trabajo es reflexionar sobre la construcción de la escritora como personaje público a partir del caso de Lucie Delarue-Mardrus y su proyección en España, situándola en el marco de las tensiones que rodean a la condición femenina a principios del siglo XX. Si bien su obra es traducida y reseñada, es su propia figura el elemento que focaliza la atención de la crítica como lo constatan las diversas referencias de cronistas destacados (Enrique Gómez Carrillo, Isabel Oyarzábal, María Luz Morales o Teresa de Escoriaza, entre otros). Este fenómeno permite ver los elementos clave de la construcción autorial femenina, como la incorporación de estrategias propias de la nueva idea de celebridad y su uso como mecanismo esencial para lidiar con la dificultad de ser mujer en la esfera pública.
\end{abstract}

Palabras clave: autoría femenina, celebridad, mujer moderna.

\section{Résumé}

Ce travail vise à réfléchir sur la construction de l'écrivaine comme personnage public à partir du cas de Lucie Delarue-Mardrus et de sa projection en Espagne en la situant dans le cadre des tensions autour de la condition féminine au début du $\mathrm{XX}^{\mathrm{e}}$ siècle. Bien que son œuvre soit traduite et fasse l'objet de comptes rendus, c'est sa personne qui attire l'attention des critiques : Enrique Gómez Carrillo, Isabel Oyarzábal, María Luz Morales ou Teresa de Escoriaza. Ce phénomène nous permet de voir les éléments clés de la construction de la figure d'auteur féminin, ainsi que l'incorporation de stratégies liées au nouveau concept de célébrité qui voit le jour et leur utilisation comme principal mécanisme essentiel pour faire face à la difficulté qu'implique, pour une femme, d'être présente dans la sphère publique.

Mots clé : Autorité féminine, auteur féminin, célébrité, femme moderne.

\section{Abstract}

The aim of this work is to reflect on the construction of the woman writer as a public figure based on the case of Lucie Delarue-Mardrus and her projection in Spain, placing her in the framework of the tensions that surround the female condition at the

*Artículo recibido el 17/06/2021, aceptado el 9/10/2021. 
beginning of the twentieth century. Although her work is translated and reviewed, it is her public figure the element that focuses the attention of the critics, as confirmed by the various references by prominent chroniclers (Enrique Gómez Carrillo, Isabel Oyarzábal, María Luz Morales or Teresa de Escoriaza). This phenomenon allows us to see the key elements of the feminine authorial construction, as the incorporation of strategies of the emerging idea of celebrity and its use as an essential mechanism to deal with the difficulty of being a woman in the public sphere.

Keywords: female authorship, celebrity, New Woman.

\section{Introducción}

Arbitraria, original, extravagante. Estos son algunos de los adjetivos que el crítico y escritor José Francés dedica a Lucie Delarue-Mardrus (1874-1945) en el amplio artículo «Escritoras francesas contemporáneas» que publica en 1911 en la revista Por esos mundos. El trabajo, en el que se alude a una amplia nómina de escritoras, como Miriam Harry, Marcelle Tinayre, la condesa de Noailles, Rachilde, etc., no solo da cuenta de la intensa atención prestada a la literatura francesa en este período sino también, y especialmente, de la fascinación por la creciente presencia de las escritoras en el campo literario; no en vano, Francés (1911: 571) ${ }^{1}$ declara: «creo en una indiscutible e interesante importancia de la moderna literatura femenina en Francia» y ubica su trabajo bajo el título «Feminismo literario». No es de extrañar esta curiosidad por las figuras femeninas que van abriéndose paso, con notable revuelo, en la esfera de las artes y las letras, pues el fenómeno emerge también en España en estas fechas. Así, como han mostrado Mangini (2001), Kirkpatrick (2003) o Capdevila-Argüelles (2008), entre otras, las primeras décadas del siglo XX alumbran la irrupción de «un nutrido grupo de mujeres intelectuales que desempeñaron un papel prominente en los avances sociales, políticos y culturales del período» (Kirkpatrick, 2003: 9).

Este trabajo pretende ubicarse en esta mirada cruzada entre la literatura española y la francesa para interrogarse sobre cómo afrontan las y los intelectuales de la época la construcción de su figura autorial y de la identidad femenina siguiendo el hilo de la presencia de Lucie Delarue-Mardrus en la prensa española y tomando como punto de partida el retrato de José Francés.

Ciertamente, existen otras referencias anteriores a Delarue-Mardrus; así, por ejemplo, encontramos la traducción de su relato «La cortesana negra» en $E l$ álbum iberoamericano el 22 de junio de 1908 y diversas referencias, desde 1904, que dan noticia de la participación de la autora en distintos actos literarios, como un homenaje a Corneille (El álbum iberoamericano, 7 de julio de 1904) o su desempeño como jurado en el premio Vie heureuse en los años 1905 (La época, 30 de enero de 1905), 1907 (La Ilustración española y americana, 30 de diciembre de 1907) y 1908 (Por esos mundos, 1 de junio de 1908). Sin embargo, el tra-

\footnotetext{
${ }^{1}$ Para facilitar la lectura se ha actualizado la grafía de esta y otras citas de textos de principios del siglo XX.
} 
bajo de José Francés no solo se detiene por primera vez en la escritora y fija un retrato determinante de Delarue-Mardrus sino que plantea, a mi entender, las coordenadas en las que las escritoras de la época se ven emplazadas a la hora de mostrarse en el campo literario. Estas podrían resumirse en la necesidad de movilizar su figura pública desde unas estrategias autoriales muy concretas, vinculadas a las dinámicas mediáticas propias de la celebridad, que incitan a las escritoras a desplegar una cuidada construcción de su personaje público en el que abundan las contradicciones, sobre todo, en lo que respecta a la gestión de su feminidad.

Este artículo quiere subrayar la necesidad de «embellecerse», mostrarse con una determinada disposición ante el público para alcanzar el éxito y/o la legitimidad como autoras; por otra, pone el foco en el volumen Embellissez-vous ! (1926), que acaparó las alusiones a Delarue-Mardrus en España a causa, como veremos, de la aparentemente irresoluble contradicción entre la imagen autorial y la publicación de consejos sobre la belleza femenina. Esta contradicción no deja de ser un acicate para desarrollar un intenso debate sobre la identidad femenina, en el que participarán algunas de las intelectuales hispánicas más destacadas del período. De ese modo, la figura de Delarue-Mardrus se convierte en un punto de partida para poner sobre la mesa los debates que se están desarrollando en España sobre la identidad femenina, el feminismo y la emancipación de la mujer.

\section{Entre la autoría y la celebridad: estrategias femeninas}

Antes de entrar a analizar la proyección de Lucie Delarue-Mardrus en el ámbito hispánico, conviene aclarar los planteamientos sobre la autoría en la modernidad que guían este trabajo. A grandes rasgos, parto de la idea desarrollada por Garval (2012), quien sugiere que desde mediados del siglo XIX, al amparo de las dinámicas mediáticas, se forja una nueva noción de fama que se nutre de la estética de lo transitorio propia de la modernidad y suplanta al modelo de fama duradera por el de la celebridad, definida por su carácter pasajero y su desvinculación de las nociones de permanencia cultural y mérito heroico. Mientras la vieja noción de fama se asocia a figuras masculinas y a la consecución de logros a través del ejercicio de las cualidades del individuo, vehiculadas en formas culturales bien legitimadas, el nuevo modelo de celebridad se relaciona con figuras femeninas cuya notoriedad más bien remite a una capacidad para mantener la visibilidad en la esfera pública y, a menudo, se vehicula en formas culturales menos legitimadas y/o más comerciales.

Esta doble concepción de la fama puede relacionarse, a mi entender, con la distinción entre autoría fuerte y débil que plantean Berensmeyer, Bueler y De Moor (2012). La autoría fuerte evocaría a las ideas de autonomía, originalidad creativa y propiedad intelectual; la autoría débil no tendría tanto que ver con estos atributos sino con el producto de determinadas redes culturales y de los actos de autorización que estas producen. Mientras que la autoría fuerte se vincularía con la idea de genio y proyectaría una imagen del autor como absoluto soberano de la obra, la autoría débil plantea al autor como comunicador de textos que están vinculados a reglas y convenciones. 
Aunque estos conceptos parecen antitéticos (fama vs. celebridad, autoría fuerte vs. autoría débil) entiendo que no lo son, sino que funcionan como campos en intersección. La autoría, al menos en la modernidad, no puede entenderse al margen del «capital de visibilidad» que surge al hilo de los nuevos regímenes mediáticos (Heinich, 2012) y en particular, al hilo de la reproductibilidad técnica que permite la difusión masiva de imágenes fotográficas. Este cambio tecnológico, que democratiza la producción de imágenes, permite a los escritores mostrarse públicamente de un determinado modo; es decir, permite reforzar la construcción de una postura autorial, esto es, la «présentation de soi d'un écrivain, tant dans sa gestion du discours que dans ses conduites littéraires publiques» (Meizoz, 2009: s.p.), mucho más efectiva y poderosa que en momentos precedentes. Esta imagen pública, vehiculada, por la fotografía, que circula como objeto autónomo y también como parte de la publicidad, la prensa, etc. no es, ni mucho menos, accesoria. Por el contrario:

Loin de constituer un élément marginal et subalterne, un seuil décoratif à valeur étroitement documentaire, les iconographies d'écrivains, dans la diversité de leurs formes, entrent au contraire en interférence dynamique avec ce que l'on considère généralement comme l'essentiel de l'expérience littéraire, à savoir l'écriture et la lecture des œuvres (Dewez y Martens, 2009: 11).

De hecho, como sugieren Ferrari y Nancy (2005), esa imagen es tan esencial que opera, en cierto modo, como una clave de legibilidad que permite hacer visible en los rasgos de un sujeto el carácter de una obra.

En definitiva, lo que quiero señalar hilando estas pocas referencias teóricas, es que el autor/a, como mínimo desde el siglo XIX, no puede entenderse solo como una figura que escribe y se expresa en sus textos -la obra- sino que es también un creador de sí mismo en un espacio mediatizado y espectacular, que da pie a la celebridad, de cuyas estrategias el/la autor/a se apropia.

El caso de Lucie Delarue-Mardrus, como el de muchas de sus contemporáneas, encaja a la perfección en este complejo entramado. Como se verá, su presencia en los medios, y particularmente en los medios hispánicos, combinará la reivindicación de las marcas de autoría (innovación, reflexión intelectual, originalidad, etc.) al tiempo que aprovecha los nuevos resortes de la celebridad (corporalidad, escándalo, exhibición de lo privado, etc.) para dotarse de una personalidad pública y afianzarse en el campo cultural.

\section{Excéntrica, poliédrica y original. La imagen de Lucie Delarue-Mardrus en España}

Como decía más arriba, el retrato de Lucie Delarue-Mardrus que ofrece José Francés en 1911 constituye un valioso texto para detectar los parámetros que determinan su imagen autorial. Arrancando con una comparación de la escritora con Charles Baudelaire, atribuida a un crítico francés que no se identifica, Francés (1911: 586) apunta que tal semejanza tiene su lógica en que la autora es «un espíritu arbitrario y original». La glosa de este espíritu es el vector que domina el tex- 
to, desplazando así el comentario sobre su obra: si bien se reconoce en ella una suerte de profetisa de la «modernísima generación literaria», «indicadora de los nuevos caminos y los ideales futuros», apenas se mencionan tres de sus obras poéticas (Occident, Horizons y Ferveurs), a las que se considera lo más sobresaliente de una producción que engloba novelas, tragedias y poemas dramáticos que ni siquiera se nombran. En contrapartida, Francés abunda en el talante de la creadora, incidiendo en su carácter provocativo («Desde sus primeras poesías, logró no pasar inadvertida. Entristece o indigna») y su actitud determinada ( «Es una gran curiosa de todas las emociones. Odia lo vulgar, lo amanerado, la placidez») a la que juzga como impostura, llegando a dudar de la «sinceridad estética» de la escritora.

Resulta casi conmovedor que el crítico concluya su retrato considerando, con una mirada displicente hacia la autora, que «la época de las extravagancias, de los desplantes y los descoyuntamientos intelectuales ha pasado para no volver...». Digo que resulta conmovedor porque precisamente su propia percepción de la autora sigue el hilo de lo que fue la estrategia de numerosas artistas e intelectuales femeninas que, aprovechando la nueva escena mediática, forjaron una imagen pública, utilizando una serie de recursos y tropos recurrentes, que trascendió tanto o más que su obra. En concreto, tres elementos interrelacionados dominaron esta imagen pública de la artista: la excentricidad, el exotismo y el juego con los modelos femeninos disponibles en la época. Estos rasgos, tendrían en común, como he explicado en otro lugar (Clúa, 2016), ser distintos avatares de la Otredad, concepto que las artistas utilizaron como recurso comercial, pero también como estrategia de acceso a y permanencia en el campo cultural.

Aunque Francés no hace hincapié en ello, es el exotismo, en concreto ligado al orientalismo, el elemento más significativo en la proyección de DelarueMardrus, tanto en España como en Francia. Son numerosísimas las referencias a este elemento, algunas tan tempranas como esta alusión de Salomé Núñez y Topete en 1908, en una columna dedicada a reflexionar sobre la posible contradicción entre belleza e inteligencia en las mujeres: «Se dice de madama Delarue-Mardrus que por la languidez de la mirada y de toda su interesante figura, parece una oriental escapada de un harén» (Núñez y Topete, 1908: 4). Si bien no es el caso de este texto, de carácter más general, esta imagen es recurrente en todos los retratos y entrevistas a la autora, aunque sea a modo de nota pintoresca, como ocurre en «Figuras del día» en la revista Cosmópolis (marzo de 1920), donde el comentario de los múltiples talentos de Delarue-Mardrus no evita el siguiente apunte: «De otra parte, por la gracia de su sonrisa, por el encanto de sus ojos, donde flota algo del misterio oriental, esta artista desarma la crítica y se hace perdonar lo que tantos dones diversos reunidos en una misma persona pudiera tener de presuntuoso» (S.A., 1920: 237).

Esta apreciación permite intuir el potencial de la adopción de una imagen orientalista, tendencia que habían iniciado actrices, bailarinas y mujeres del espectáculo como Sarah Bernhardt, Ida Rubinstein o Cléo de Mérode al hilo de las transformaciones culturales que promovieron nuevos modelos de consumir lo «ex- 
tranjero» fragmentariamente gracias a fenómenos como los museos, los grandes almacenes, las exposiciones universales o los programas de variedades (Clayton, 2012: 32) ${ }^{2}$. En ese marco, la utilización de lo oriental resultaba rentable, pero tenía otros alcances, en la medida en que el tropo orientalista estaba atravesado por una retórica de la alteridad que también atañía a lo femenino ${ }^{3}$; así, esa «performance of otherness» (Mesch, 2013: 86) fijada, en buena medida, en las imágenes implicaba la posibilidad de encauzar de manera coherente y eficaz el carácter disruptivo que, por definición, cualquier creadora tenía. A fin de cuentas, la exhibición de una imagen orientalizada caía dentro de la adopción de una personalidad excéntrica lo que no dejaba de ser una estrategia que permitía lidiar con el hecho de desafiar el rol normativo de la mujer recluida en la domesticidad y convertir el hecho de ser una figura poco convencional en un elemento atractivo y en cierto modo tolerable (Roberts, 2002). Por otra parte, el tropo de lo oriental también jugaba con los imaginarios femeninos disponibles en el momento y tenía numerosas implicaciones en materia de género y sexualidad; así, como sostiene Apter (1994), muchas artistas francesas de la época movilizaron estereotipos orientalistas para modelar nuevas identidades sexuales:

Orientalism, as a nexus of extravagant psychic investments and layered semblances of the type, evolved into feminist and lesbian camp for a number of other more obvious reasons. Not only were women empowered or accorded sexual license through association with the dominatrix characterologies attached to exemplary princesses, queens, seductresses or women leaders of the East, but, more interestingly, their agency was enhanced by "being" these avatars both on stage and off. Ida Rubenstein, Sarah Bernhardt, Mata Hari, Colette, Lucie Delarue Mardrus, and others expanded the performative parameters of this topic stereotype by moving their larger-than-life thespian personas into the choreography of erotic everyday life (Apter, 1994: 109).

Más allá de la vinculación entre el uso de la parafernalia oriental y la creación de identidades genéricas y sexuales disruptivas, me interesa subrayar cómo el hecho mismo de poner en escena esas identidades en diálogo con los imaginarios al uso, suponía una actitud plenamente moderna, por la que la subjetividad se construye desde el exterior en un juego en el que las fronteras entre ser, parecer y fingir se desfiguran. Tal densidad significativa explica que la imagen oriental

\footnotetext{
${ }^{2}$ Sobre la relevancia de este fenómeno, particularmente en el ámbito de la danza, véase Ross Dickinson (2017).

${ }^{3}$ Cabe recordar que es Said en su influyente Orientalism quien señala la concepción de Oriente como un espacio feminizado dentro de una retórica de la diferencia en la que Oriente se caracteriza por «its eccentricity, its backwardness, its silent indifference, its feminine penetrability, its supine malleability» (Said, 1979: 206), características que las performances orientalistas de artistas y escritoras ponen también en circulación.
} 
formara parte de la iconografía de la mujer escritora que se va forjando en los medios a principios del siglo XX (Mesch, 2013).

Es en este contexto donde debe insertarse la puesta en escena orientalizante que Lucie Delarue-Mardrus despliega y que recoge la prensa española, apoyándose, en numerosas ocasiones, en la imagen fotográfica y otros paratextos. Sucede así en la larga semblanza que Mariano de Alarcón escribe en 1923 para la revista Elegancias, que está encabezada por una fotografía en que la autora aparece con indumentaria oriental y en una pose que recuerda a una esfinge [Imagen 1].

La sofisticación de la puesta en escena no deja dudas en cuanto a la intencionalidad a la hora de buscar una identificación con lo oriental y la dedicatoria autógrafa que la acompaña va en la misma dirección, evocando un Oriente misterioso, remoto, que parece poseerla, y desplegando una actitud entre mística y esotérica:

Ah ! Je suis dans la mort, je suis ici chez moi.

La déesse est couchée entre les griffes ! La déesse est couchée au fond des sarcophages ! La déesse est sur tous les éternels visages ! Elle circule, elle palpite, je la sens...

- Égypte, à moi ! J'ai la déesse dans le sang (DelarueMardrus apud Alarcón, 1923: 18)

Curiosamente, como veremos más adelante, la crónica de Alarcón apenas recala en este aspecto y las referencias a Oriente se reducen a constatar en tres líneas los numerosos viajes de la autora a este entorno y su evocación en algunas de sus obras. Pese a ello, que la crónica esté presidida de manera tan notoria por estos dos elementos determina intensamente la imagen de Delarue-Mardrus, fenómeno que va más allá de este artículo en concreto. 


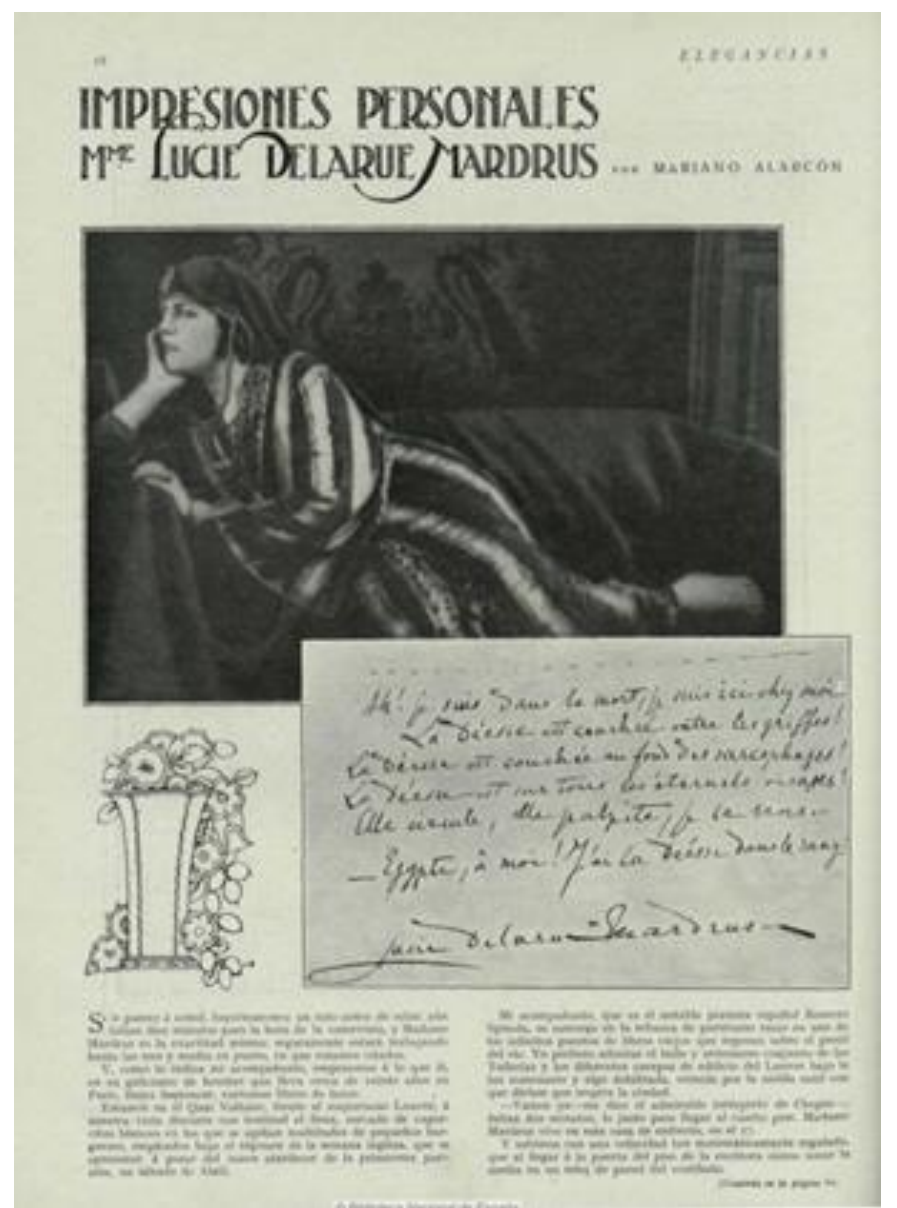

Imagen 1. Fotografía y dedicatoria de la autora en la revista Elegancias (1923). Fuente: Biblioteca Nacional de España.

Como señala Collado (2003), estas imágenes orientalizantes fueron fundamentales en la trayectoria de la autora pues tuvieron un rendimiento práctico indudable: por una parte, ayudaron a vender sus reportajes de viajes y por otra, le permitieron forjar en la opinión de la época una imagen cautivadora de princesa oriental. Así puede apreciarse en varias de las descripciones de la autora, por ejemplo, en la semblanza de los integrantes del premio Vie heureuse de $1907^{4}$, donde esta fascinación señalada por Collado se combina con una oportuna conexión con rasgos de autonomía expresiva y originalidad que funcionan como marcas de autoría fuerte:

[...] les larges beaux yeux sous la coiffure nattée tout autour de la tête -ce qui est une manière charmante d'être couronnée de lauriers- l'immobilité, l'air d'observer, les vêtements flottants composent à celle que les Arabes nomment si bien

\footnotetext{
${ }^{4}$ Cabe destacar que todas las semblanzas están acompañadas de retratos fotográficos de las integrantes del jurado que aparecen en pie de igualdad con el texto, pues cada uno ocupa una página entera del folleto. Es, pues, una muestra clara de la relevancia de la imagen fotográfica en el emplazamiento de las autoras en el campo literario.
} 
«la Princesse Amande», un aspect de fée, de prêtresse et d'enfant. Elle possède une puissance et une fougue bien rares chez une femme, une originalité absolue et multiple, une hardiesse raisonnée et pleine d'équilibre (S.A., 1907:

12).

El peso de la imaginería oriental en la recepción de la autora lo encontramos también en el artículo «Siluetas del mundo francés. Lucie Delarue-Mardrus» firmado por Beatriz Galindo (seudónimo de Isabel Oyarzábal) y publicado en $L a$ esfera en 1921. De entre todas las piezas de prensa consultadas, me atrevería a decir que es este el trabajo que entra de manera más clara en el terreno de la crítica literaria propiamente, ofreciendo una completa y cabal panorámica de la producción y los temas de la escritora. Sin embargo, el texto queda eclipsado por el material fotográfico, que domina la página [imagen 2] e incluye una fotografía de «Mme Delarue-Mardrus, con indumento oriental», muy semejante, por ejemplo, al atuendo que lucía la famosa bailarina Tórtola Valencia algunos años antes en la Danza del Incienso.

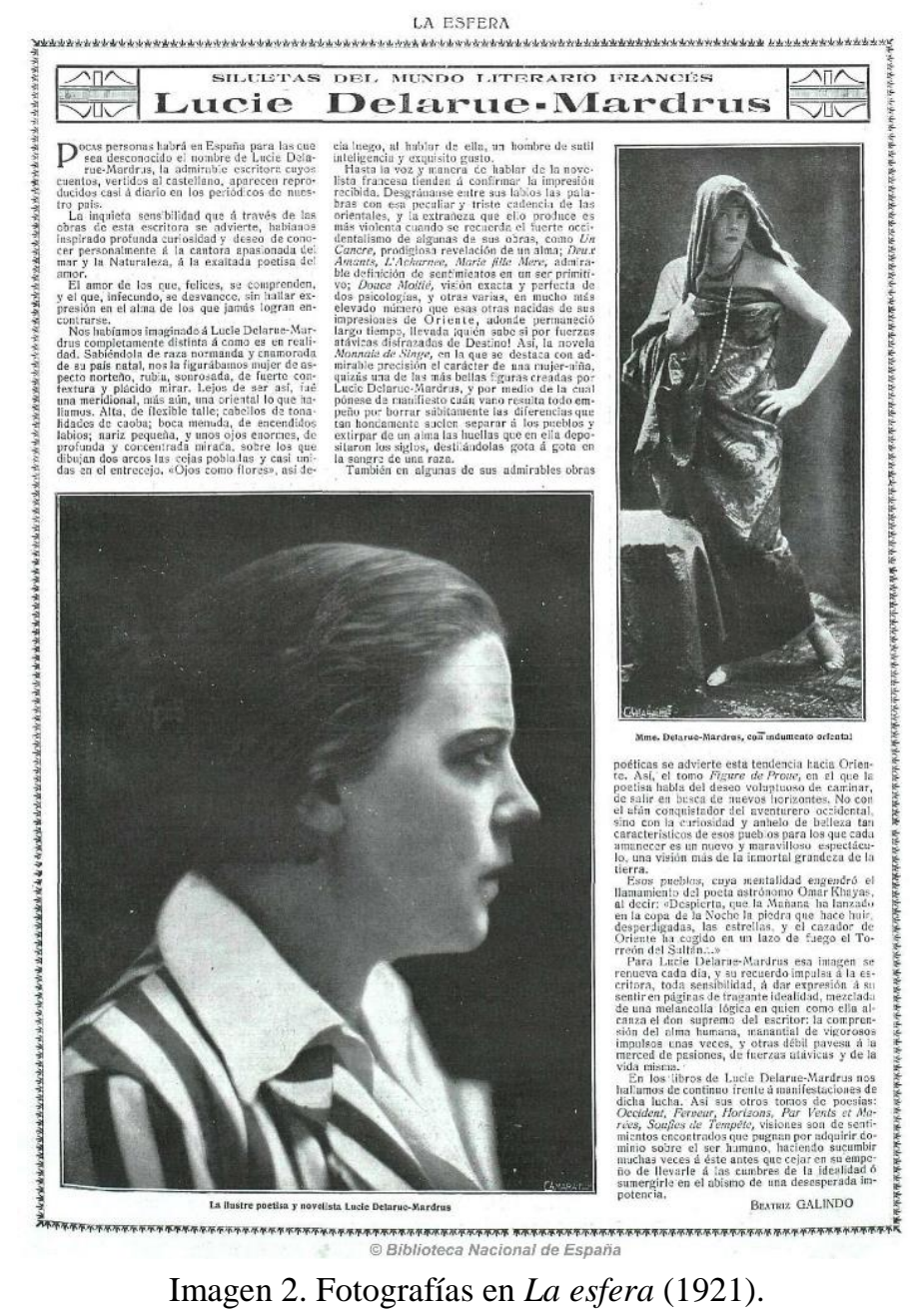


Fuente: Biblioteca Nacional de España.

El diálogo de esta fotografía con el resto del material sigue dos caminos distintos; por una parte, el texto de Oyarzábal que, como ya se ha dicho, evidencia un genuino interés por explicar la obra de la artista, no puede escapar del tropo de la imagen oriental de la escritora francesa, si bien, ejerciendo plenamente el oficio de crítica literaria, lo circunscribe solo a algunas obras, subrayando el talante occidental de otras:

Sabiéndola de raza normanda y enamorada de su país natal, nos la figurábamos mujer de aspecto norteño, rubia, sonrosada, de fuerte contextura y plácido mirar. Lejos de ser así, fue una meridional, más aún, una oriental lo que hallamos. Alta, de flexible talle; cabellos de tonalidades de caoba; boca menuda, de encendidos labios; nariz pequeña, y unos ojos enormes, de profunda y concentrada mirada, sobre tos que dibujan dos arcos las cejas poblarlas y casi unidas en el entrecejo. «Ojos como flores», así decía luego, al hablar de ella, un hombre de sutil inteligencia y exquisito gusto.

Hasta la voz y manera de hablar de la novelista francesa tienden a confirmar la impresión recibida. Desgránanse entre sus labios las palabras con esa peculiar y triste cadencia de las orientales, y la extrañeza que ello produce es más violenta cuando se recuerda el fuerte occidentalismo de algunas de sus obras (Galindo, 1921: 4).

Por otra parte, el texto de Oyarzábal está acompañado de una segunda fotografía, un retrato de perfil de la escritora, en el que se muestra con un aire notablemente masculinizado. El contraste con la imagen hiperfeminizada à la oriental, con la que comparte página, parece apuntar a una contradicción; sin embargo, tal disparidad no solo es un rasgo recurrente en la proyección de la autora-«Mardrus took great pleasure in displaying her own physical beauty, sometimes on the covers of magazines or in self-portraits, and in accepting male attributes» (NewmanGordon, 1994: 114) - sino que resulta notablemente coherente: tanto la imagen orientalizada como la masculinizada suponen una performance de una identidad genérico-sexual que escapaba de los parámetros al uso al tiempo que alimentaba la fascinación del público sugiriendo una personalidad caleidoscópica y única directamente relacionada con su obra. Ello puede apreciarse en las palabras que le dedica Gabrielle Réval, en las que fantasea con el abanico de imágenes de Delarue-Mardrus que podrían adornar un posible museo en honor de la escritora, donde sus seguidores la verían:

La voici en Sirène avec des poissons d'or et d'argent qui scintillent autour d'elle; en figure de proue, immobile à la barre du bateau qui l'emporte ; en musulmane, traversant le désert sur le dos du méhari ; en jeune garçon botté et chapeauté qui a le charme ambigu du chevalier d'Eon; en cowboy, sur le cheval que l'intrépide nomma par amitié: CœurVolant ! La voici avec les voiles, les colliers et les amulettes d'une femme de harem ; sous le burnous du chanteur arabe, 
accroupi sur le sol et psalmodiant ses chansons tristes. Enfin, debout, robuste et fière, comme l'Ève qui vient de naître, coiffée de ses cheveux en couronne, taillée dans la pierre, comme un antique par le ciseau habile d'Yvonne Serruys.

Ces multiples images fixent les aspects divers d'une curieuse individualité qui se plaît par instinct ou par fantaisie d'artiste à ces métamorphoses.

Lucie Delarue-Mardrus est aussi variée dans les manifestations de son esprit qu'elle l'est dans ses attitudes et dans ses atours. Elle est poète, romancière, peintre, sculpteur, violoniste et même écuyère, une écuyère qui rêve des prouesses du cirque (Réval, 1924: 56-57)

Réval no solo sitúa a Delarue-Mardrus en la retícula de las imágenes de feminidad disponible en la época -desde la femme fatale hasta la virago-, sino que conecta la apariencia poliédrica de la escritora, su exterioridad, con una interioridad particular que se vierte también en la obra literaria ${ }^{5}$. Este detalle es importante, puesto que dentro de las estrategias de autoriales de la modernidad, esta conexión entre el cuerpo mostrado y la sensibilidad artística va a ser recurrente y se va a extender incluso a los espacios privados. Así, como señala Eméry (2017), desde finales del siglo XIX proliferan las imágenes de personajes conocidos en la intimidad de su hogar, lo que, en lo que se refiere al campo literario, supondrá un elemento clave en la canonización de los autores y fijará una iconografía de la autoría literaria muy determinada: la del escritor sentado en el escritorio, con la cabeza apoyada en la mano o sujetando una pluma o libro, imagen que, a nivel simbólico, apunta al trabajo duro que este desempeña (2017: 6). Este tipo de imagen, que recalca el oficio de escritor, es la incluida en la serie Nos contemporains chez eux, de Dornac, en la que Delarue-Mardrus aparece sentada con un libro entre las manos y también en el artículo de José Francés antes mencionado en la que vemos, en un primer plano muy cerrado, el rostro de la autora leyendo un libro.

\footnotetext{
${ }^{5}$ Más concretamente, el texto de Réval parece aludir al poemario Figure de proue (1908): en él, la poeta no solo se identifica con esta figura en el poema liminar, sino que su temática orientalista desgrana algunos de los elementos y escenarios que Réval menciona.
} 


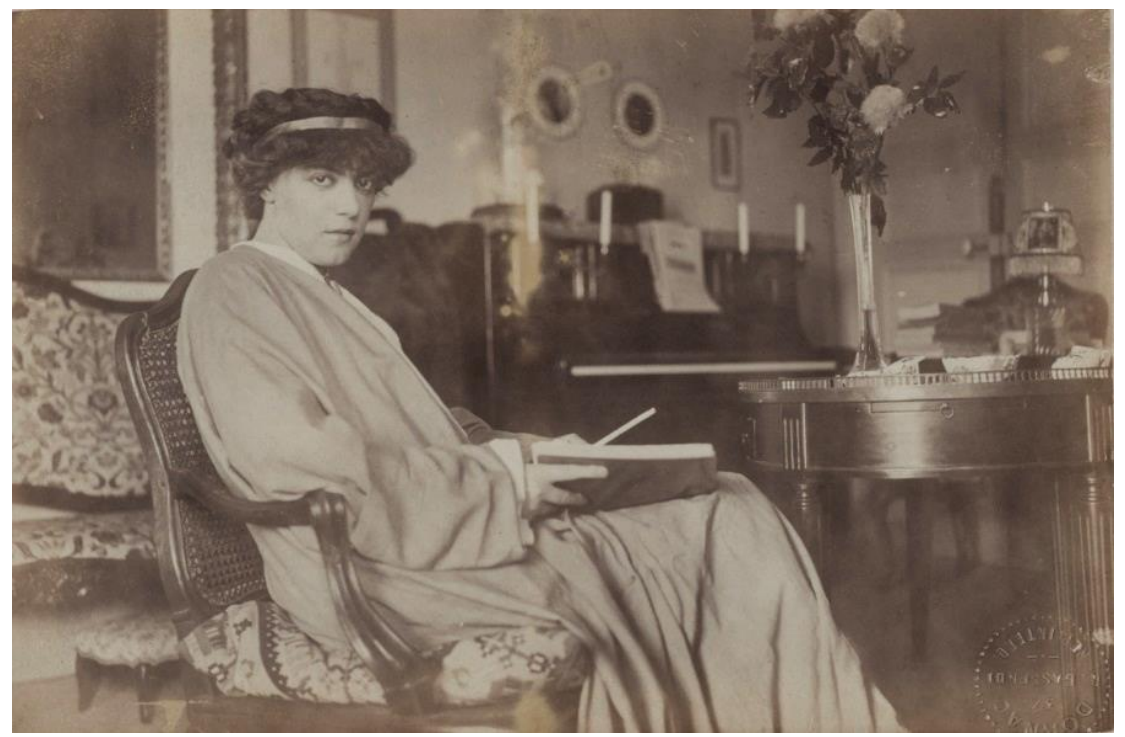

Imagen 3. Lucie Delarue-Mardrus en 1909 en la serie de Paul Dornac Nos contemporains chez eux. Fuente: Bibliothèque National de France.

Otras fotografías, en cambio, rehuirán de esta disposición canónica para enfatizar la dimensión estética del hogar como correlato de una particular sensibilidad artística, de suerte que una determinada decoración, que habitualmente escapa de las convenciones y el gusto burgués viene a consagrar el mito del interior artístico superior del sujeto que se muestra en ese entorno (Émery, 2012: 41). Si bien las imágenes de Delarue-Mardrus de este tipo no abundan en la prensa española, que prefiere retratos de estudio y las poses y atuendos ya comentados, esta conexión entre hogar y desempeño artístico sí se puede detectar. De hecho, articula prácticamente la totalidad de la crónica de Mariano de Alarcón, quien se detiene en la descripción del hábitat de la escritora:

Entramos. La ilustre poetisa nos espera ya, de pie, en medio de su despacho, mezcla de salón de música, estudio de pintor y biblioteca. En los estantes se apretujan los libros, ya en rústica, ya ricamente encuadernados; en el muro de enfrente, el piano abierto; sobre el piano, un violín, a cuya base adhiérese una diminuta almohadilla de terciopelo; cerca, hacia el rincón, un atril, sobre el que reposa, abierta, una particella de Schumann; en el rincón opuesto, una reproducción en tamaño natural de una de las Venus del Vaticano; un amplio diván turco, cubierto de ricas telas orientales, en el otro lienzo de pared; y en medio de la estancia, la gran mesa «Imperio», donde se amontonan libros a medio leer, a juzgar por las plegaderas que los incinden [sic]; carpetas con los títulos de diferentes trabajos literarios por concluir; dos ceniceros preciosamente cincelados; cajas de cigarrillos egipcios; objetos, en fin, con presencia de seres inanimados; como ser animado, junto a la escribanía, en un supremo desdén de las personas que conversan, durmiendo dulce y pausadamente, un 
enorme gato de suave piel leonada, que una respiración profunda y tranquila comba y abaja con isocronismo de onda de oro (Alarcón, 1923: 62).

Siguiendo la clave de lectura de Émery, el espacio privado de la escritora se sitúa fuera de los valores utilitaristas burgueses por su profusión de objetos ornamentales, suntuarios y exóticos, sugiriendo en esa puesta en escena su propia personalidad. Más aún, la crónica de Alarcón recoge cómo ese decorado da pie a Delarue-Mardrus a desplegar una exhibición en toda regla de sus múltiples habilidades artísticas:

Y así nos enteramos de las pasiones que la absorben todo el tiempo que no dedica a la labor literaria: la equitación, la pintura, el violín. De suerte que, al ver los cuadros que se disputan el espacio de las paredes - paisajes, en su mayor parte-, sentimos aumentar el interés que nos inspiran, cuando, con palabra lenta y expresiva, la autora nos describe los lugares en que fueron naciendo de sus propios pinceles. Y la voz de la artista se calienta y colorea con la evocación de su tierra natal de Bretaña.

Y de su maestría de violinista adquirimos la certidumbre cuando, acompañada por Homero, interpreta la obra de Schumann que reposa en el atril, a la que siguen otras de Haendel, Debussy, Frank...

$\mathrm{Y}$ de sus aptitudes de ecuyére [sic] cuando, mientras tomamos el té, nos muestra fotografías de festivales y carruseles de caridad, a cuyo esplendor hubiera de contribuir infinitas veces con proezas de amazona (Alarcón, 1923: 62).

Aunque el párrafo parece centrarse en aspectos personales -gustos y aficiones- de Lucie Delarue-Mardrus, lo cierto es que esta exhibición de otras pasiones que la ocupan es coherente con la imagen poliédrica que he venido comentando hasta ahora y que atañe también a la multiplicidad de facetas que despliega en su quehacer literario. De ese modo, su nutrida y variada producción, inserta en este contexto, nos conduce a interpretarla como una manifestación más de ese espíritu cambiante y metamórfico que también podemos apreciar en el caleidoscopio de imágenes fotográficas mediante las que se muestra

Ahora bien, si todos estos signos que vengo comentando apuntan a una construcción autorial «débil», próxima al nuevo modelo de fama que describe Garval, esto es, basado en la exhibición mediática y la estética de lo transitorio, ello no obsta para que este se combine con el modelo de autoría fuerte, como podemos detectar en la misma crónica de Alarcón. En esta, en cierto momento, el periodista hace notar que esa pasión desbordante de la autora está perfectamente canalizada en una férrea disciplina de trabajo que la propia interesada subraya, aprovechando la coyuntura para publicitar algunos de los diarios y colecciones en los que publica:

Pero en Madame Lucie Delarue Mardrus, novelista, poetisa, cuentista admirable..., la literatura no es una pasión; es más: 
constituye una devoción apasionada, una labor diaria tenaz y continua y entusiasta... Tanto que, al inquirir con mi única pregunta de interviú: «¿Trabaja usted mucho, Madame Mardrus?», me contesta:

- Siempre. No puedo hacer de otro modo, si he de cumplir con la voracidad de mis editores... Y, además, los diarios; figúrese usted, sólo cuentos, doce al mes para Le Journal, Le Petit parisien, L'Intransigeant, Excelsior... De vez en cuando una novela para el tomo mensual de Les CEuvres Livres, y alguna traducción que me interese personalmente, como las que estoy haciendo ahora, en verso, de seis poemas de Edgar Poe (Alarcón, 1923: 62).

Este deliberado énfasis en las cualidades vinculadas a la autoría fuerte se hace aún más evidente en la crónica firmada por Adolphe Falgairolle en Blanco y negro (7 de agosto de 1927), que permite ver, al yuxtaponer las declaraciones de la escritora con los comentarios del periodista, la eficiencia de esta estrategia:

¿Mis débuts? A los cinco años ya escribía en verso, pero en inglés... Después componía cinco o seis poemas al día. Ya puede usted pedirme una balada, un soneto. Yo bato el record de rapidez en composición poética. (Esto es lo que da al estilo de madame Delarue-Mardrus la ligereza volátil. En todas sus novelas se insurrecta contra las fealdades de la vida y las sujeciones de la civilización; por ejemplo, en La Monnai $d u$ Singe [sic].) Comencé tarde a escribir en prosa. Esto me es más difícil (¿quién lo creyera al leer estos encantos de emoción que son los cuentos del Journal?). Todavía era una chiquilla cuando empecé mi primera novela. Tanto se burlaron de mí mis hermanas, que tuve que esconderla debajo del colchón. Era una historia de niños, pues ninguno me parece lo mismo; la rubia de ojos verdes, la morena de ojos azules... escribía durante las clases; pero en composición francesa... era yo la última. (Sin embargo, madame Delarue-Mardrus lleva fama por la severidad de su prosodia, en la que no admite ninguna de las perezosas concesiones del verso moderno) (Falgairolle, 1927: 21).

El relato de la precocidad, las habilidades técnicas y la diversidad de talentos no se detiene aquí y abarca, entre otros, los conocimientos del árabe y la pericia en la pintura, sin olvidar que toda la crónica se realiza con motivo de la realización de una escultura en honor a santa Teresita de Lisieux. En cualquier caso, lo que me interesa señalar es cómo esas declaraciones tejen una imagen autorial, esta vez sí, basada en el talento y en unas cualidades extraordinarias que el periodista pone en relación con los rasgos de la obra literaria de Delarue-Mardrus. Aunque la crónica se cierra con esta petición de la autora: «-Nada de réclame, le ruego estalla madame Delarue-Mardrus» a propósito de la publicación de un libro «en el que enseña a las mujeres a pintarse con mesura y en el que da preciosos consejos 
y recetas de belleza», parece evidente la activa autopromoción que la autora lleva a cabo en sus interacciones directas con la prensa.

La apelación a cualidades creativas vinculadas al modelo de autoría fuerte y masculina debe entenderse, en mi opinión, no solo como un juego con las múltiples opciones disponibles para proyectarse en la esfera pública, sino también como una necesidad para legitimar la condición de mujer y autora. Recalcar la disciplina, el rigor intelectual, el sentido del trabajo suponía una forma de contrarrestar la visión, a veces condescendiente, a veces agresiva, pero siempre misógina, que dominaba en la época y que solía vehicularse en una constelación de conceptos en los que la supuesta sensibilidad femenina rozaba lo patológico y evocaba el desorden. No faltan alusiones en este sentido en la prensa española, si bien pocas tan elocuentes como la descripción que le dedica Antonio G. Linares (1924: 32): «figura trepidante y excéntrica de esa legión que en nuestros días se tiene por intelectual, sufre de nervosismo y confunde tan vulgar inquietud con la fiebre divina del genio». Pero es el artículo de Enrique Gómez Carrillo «El veneno del romanticismo en las poetisas» $(A B C, 1$ de agosto de 1923) el que nos informa con mayor claridad de este contexto al reproducir las opiniones de Charles Maurras en «Le Romantisme féminin -Allégorie du sentiment désordonné» (1917), referidas no solo a Lucie Delarue-Mardrus, sino también a Renée Vivien, Madame de Régnier y la condesa de Noailles. Así se refiere Gómez Carrillo a la postura de Maurras:

Viendo lo que, según sus teorías, hay de deletéreo en la poesía febril de las cuatro sirenas, nos hace observar cuan rebeldes son las mujeres en general, y las mujeres nacidas fuera de Francia en particular, a la disciplina greco-latina, que sólo la educación parisiense encarna dentro del mundo moderno. -Esas metecas indisciplinadas -dice, repitiendo una frase de Dauchot- están envenenadas por el romanticismo (Gómez Carrillo, 1923:1).

Si bien Maurras es un intelectual con una ideología muy marcada, la alineación de la rebeldía, la indisciplina, lo sentimental y lo febril resultaba habitual en la percepción de la feminidad y, como apunta certeramente Gómez Carrillo, de la creatividad de las mujeres. En este marco se puede entender mejor, pues, la necesidad de Delarue-Mardrus y de otras contemporáneas a la hora de combinar la explotación de su imagen más espectacularizada con la medida apropiación de cualidades propias de la autoría masculina.

\section{Mirarse al espejo: modelos femeninos en controversia}

La tensión entre una postura autorial modelada sobre rasgos más convencionales asociados a las figuras masculinas y otra construida en aspectos más novedosos, como la exhibición mediática y la explotación de determinados imaginarios de la feminidad, toma nuevos derroteros con la publicación de Embellissezvous! (1926) y otros textos de la misma temática, que capitalizan en España bue- 
na parte del interés sobre Lucie Delarue-Mardrus ${ }^{6}$. Desde luego, la producción de la autora dedicada a dictar consejos de belleza para el público femenino es de lo más comentado en la prensa española de la época; pero más allá de la abundancia de referencias a estas obras, interesan porque trasladan a un debate más amplio la significación de la autora, configurándola como referente de un nuevo modelo de creadora y de mujer, una mujer moderna que mantiene una contradictoria relación con elementos como la moda, el maquillaje o el consumo de bienes suntuarios. Esta contradicción es patente en algunas de las revistas con las que DelarueMardrus colabora, como Femina y La Vie heureuse, en las que la «femme moderne offered an inspiring image of "having it all" in the Belle Epoque -devoted husband, fulfilling family, beautiful home, and, if not a satisfying vocation, at least some sort of outlet for self-expression, all while maintaining her impeccable appearance» (Mesch, 2003: 4).

Así, ambas publicaciones:

[...] celebrated achieving women in dazzling feature stories sandwiched between elaborate fashion plates and advertisements for beauty creams, corsets and high-end furniture. Regardless of the nature of their achievements -not just as writers, but as lawyers, doctors, actresses, explorers or athletes- their femininity remained fully and vividly intact (Mesch, 2003: 1).

Ciertamente, como se plantean algunos cronistas, puede parecer paradójica la compatibilidad de una carrera como creadora con la difusión de consejos sobre maquillaje y peluquería, pero esta contradicción forma parte del mismo concepto de nueva mujer que la escritora y sus colegas, así como las lectoras de tales publicaciones, encarnaban y/o aspiraban. En este sentido, las referencias a elementos tradicionalmente relacionados con lo femenino, como es el caso de la moda o la cosmética, distaban mucho de mantener los significados tradicionales que conectaban a la mujer con la superficialidad, el cuerpo y el dominio de lo material y la cosificación; por el contrario:

If femininity can be seen as a form of belittlement, associated with demure, the dainty and the unassuming, then glamour -it can be argued - could offer a route to a more assertive and powerful form of female identity. Glamour was often linked to a dream of transformation, a desire for something

\footnotetext{
${ }^{6}$ La importancia de esta obra en la recepción no se debe a una cuestión cuantitativa ni a que el texto resulte especialmente controvertido; lo que resulta controvertido es su temática por la contradicción que genera en lo que se refiere a la imagen autorial el hecho de abordar un tema aparentemente frívolo como la belleza. Entre las más de 60 referencias a la autora que he rastreado en la prensa entre 1908 y 1936, predominan las que aluden a su obra estrictamente literaria -ya sea como noticia de la publicación, traducción de sus obras, noticia de su participación en actividades literarias...-, pero en esos casos tienen carácter meramente informativo o valorativo. En cambio, las referencias a este libro se enmarcan en piezas donde se debaten, precisamente, los modelos de feminidad y autoría de la época.
} 
out of the ordinary, a form of aspiration, a fiction of female becoming (Dyhouse, 2010: 2-3).

Del mismo modo, Wilson (2007: 97) -que sitúa la emergencia del glamour en la figura del dandy decimonónico- señala como el individuo glamouroso «imposes himself upon society by means not of power but of beauty and personality, unanchored and divorced from traditional social relations», de suerte que podemos entender que el cultivo de la apariencia tenía un potencial emancipador que, dicho sea, también afectaba al consumo -elemento subyacente a la promoción de los productos de moda y belleza-, que desde finales del siglo XIX se percibía, en parte, como uno de los escasos espacios de autonomía para el sujeto femenino (Felski, 1995: 65).

Las incursiones de Lucie Delarue-Mardrus -pero también de otras escritoras y aristas como Liane de Pougy, Lina Cavalieri y Colette, en Francia o Carmen de Burgos, en España ${ }^{7}$ - en este territorio de lo frívolo y lo femenino deben entenderse en esta ambivalencia que también se percibe en la época, pues incluso las referencias al libro más adheridas a la difusión de consejos prácticos de belleza dan pie a interesantes reflexiones sobre la idea de feminidad.

Sucede así en la columna que Matilde Muñoz publica el 3 de diciembre de 1925 en la sección «Lecturas para la mujer. El hogar y la moda» de El imparcial. Aunque la pieza deriva hacia recomendaciones concretas acerca de cómo maquillarse el rostro y los labios y qué cuidados ha de recibir el cabello, se inicia con una curiosa introducción en la que Muñoz se nos muestra como una lectora avispada y cómplice de la obra de Delarue-Mardrus, pues es capaz de traspasar la aparente frivolidad del texto para subrayar la labor intelectual de la francesa:

Ahora ha sido una exquisita escritora francesa, Lucia Delarue-Mardrus, autora de muchos libros encantadores, quien ha llevado al caudal de las letras una nueva obra titulada Seducir. Ensayos sobre el arte de embellecerse, y bajo cuyo sugestivo título pueden encontrarse tantas cosas interesantes, profundas, estéticas y regocijantes. Figuraos que Lucia Delarue-Mardrus lleva sus consejos, muy razonados y muy ingeniosos, a los terrenos de la Filosofía, de la Arqueología y de la Historia, lo cual siempre es un poco expuesto. El investigar las causas de la belleza puede llevar a desilusiones penosas. Lo que era bellísimo en Asiria puede ser abominable en

\footnotetext{
${ }^{7}$ Liane de Pougy, además de ser una famosa cortesana fue la directora del semanario femenino L'art d'être jolie (1904-1905), que fue traducido y editado en España por Eduardo Zamacois. Lina Cavalieri estuvo, precisamente, a cargo de la columna sobre belleza, «L'art d'être belle» en Femina a partir de 1911 y publicaría volumen completo con sus consejos en 1914 (My secrets of beauty); había abierto tiendas de cosméticos en Nueva York y acabaría inaugurando su propio salón de belleza en París en la década de 1920 (Gundle, 2007). También Colette publicó numerosos artículos de esta temática tanto en la prensa generalista como femenina, llegando a tener su propio instituto de belleza (Grout, 2020). Carmen de Burgos, por su parte, publicó, entre otros, $E l$ arte de seducir: tesoros de la belleza (1916), Salud y belleza: secretos de higiene y tocador (1918) o El arte de ser mujer: belleza y perfección (1920).
} 
Roma, y las bellezas perfectas del Japón harían poner a los hombres de Occidente el gesto de un gato que se ha tragado una espina. La escritora ilustre analiza el porqué de la seducción a través de las civilizaciones y las razas (Muñoz, 1925: $5)$.

Pero esta apreciación de la escritora sucede a una interesante y ambivalente reflexión sobre la condición femenina, con la que se abre la columna, que deriva en una referencia a otra de las figuras más controvertidas de la época: la sufragista.

Seducir ha sido la preocupación de todas las edades. La preocupación de los hombres y la de las mujeres. Una especie de batalla galante que corre a través de los siglos y en cuyos lances toman parte las ciencias, las artes y los recursos todos del ingenio humano. Los sexos desean saber cuál es el más fuerte, y quiere probarlo cada uno con la conquista del otro. Pero reconozcámoslo y hagámoslo reconocer así. Hasta ahora el sexo más débil en este terreno es precisamente al que se da el nombre de fuerte. Por cada don Juan triunfante, $\mathrm{y}$ al fin y al cabo preso en las redes de sus propias conquistas, ¿con cuántas como doña Inés podemos contar nosotras? Y doña Inés, ¿no fue en la realidad la que sedujo a don Juan? ¿No son, en realidad, los grandes seductores en el fondo unos eternos seducidos? Dejemos a Freud este problema y dediquémonos nosotros a otro más sencillo, si bien tiene su raíz en el mismo asunto. No nos ocupamos de la filosofía de la seducción, sino de la estrategia de esa acción de episodios seculares que han empeñado en dura lucha a los dos sectores en que se divide la Humanidad.

Esta es cosa, por ejemplo, que nunca comprenderán las sufragistas, que se creen llamadas a la vida para empleos más trascendentales, pero a las que en el fondo toda mujer presta la mejor atención (Muñoz, 1925: 5)

Las palabras de Muñoz parecen sugerir un cierto rechazo a la imagen de la sufragista, a la que se le atribuye una renuncia de aspectos propiamente femeninos. En cierto modo, la postura de la periodista, con su glosa de las aptitudes de Delarue-Mardrus y sus meticulosos consejos de belleza, apunta, en efecto, a la posibilidad de «tenerlo todo» a la que se refería Mesch (2013). Esta actitud es extensible a otras escritoras como Teresa de Escoriaza, quien dedica un artículo a Delarue-Mardrus y sus consejos de belleza en La libertad (5 de enero de 1927). A diferencia, como veremos, de otros cronistas masculinos, Escoriaza, igual que Muñoz, despliega una lectura muy matizada de la escritora francesa, que apunta a una reflexión compleja sobre la condición femenina. Así, Escoriaza, aunque entra de lleno en las consideraciones sobre el cultivo de la belleza para agradar al hombre que Delarue-Mardrus postula, no descuida el énfasis de esta en la necesidad de que la mujer se forme y sea independiente (aspecto este que quedará totalmente 
obliterado en las apreciaciones de sus homólogos masculinos); igualmente esta aparente disyuntiva sobre las aspiraciones femeninas da pie a que Escoriaza establezca un contraste con otros modelos de mujer, la feminista, plenamente identificada con la virago, y confronte a todos ellos con el de los moralistas y predicadores que denigran la belleza y el artificio femenino:

En la obra titulada «Embelleceos», la señora Delarue Mardrus, a la par que incita a sus hermanas a estudiar, a ilustrarse y a trabajar, proclama que «la principal misión de la mujer sigue y seguirá siendo la de gustar al hombre», y apoya esta afirmación suya en las de otras mujeres insignes, como Mme. de Staël, que decía: «La fama no es sino un vago aroma de la felicidad». Y prosigue para sostener diciendo: «¿Cómo puede ser la mujer si no es amada? Y ¿cómo puede ser amada si no es bella o, por lo menos, si no tiene un aspecto agradable de contemplar?»

Con éste y otros argumentos semejantes, y sobre todo, por ser quien es la que los sostiene, Mme Delarue Mardrus habrá de contrarrestar de un modo decisivo la influencia que venían ejerciendo las feministas propagadoras del «viraguismo», influencia harto más positiva que la de los moralizadores que poco o nada logran. [...] Aunque, por lo que pudiera suceder también la defensora del régimen rojo se previene contra los predicadores que consideran los artificios de la «toilette» como una inmoralidad y opinan que la conciencia escrupulosa de una mujer buena debe de dictar a ésta una conformidad absoluta con lo que la Naturaleza le haya dotado (De Escoriaza 1927: 1).

La fina apreciación de Escoriaza sobre la exaltación de una feminidad natural, alejada del artificio y su acompañante implícito, la vanidad, por parte de determinados discursos normativos permiten entrever el potencial subversivo del embellecimiento; al mismo tiempo, de manera tácita, pone sobre la mesa la dificultad de la mujer para encajar en los ideales contrapuestos que circulan en ese momento. Si bien muestra mayor simpatía hacia las «feministas propagadoras del viraguismo» que hacia los moralistas, tampoco se inclina abiertamente hacia aquellas. En ese sentido, aunque no se centre en la cuestión de la belleza, resulta significativo el artículo de María Luz Morales en las «Páginas femeninas» de El Sol, titulado «Dios...y los pucheros». También Morales apela a Delarue-Mardrus a propósito de los modelos femeninos y en concreto de la encuesta lanzada en $L a$ femme de France acerca de si es más conveniente que un intelectual elija como compañera a una mujer culta o sencilla ${ }^{8}$. Morales, de manera muy inteligente y

\footnotetext{
${ }^{8}$ Aunque no sea objeto de este trabajo, por razones de extensión y coherencia, resultan muy significativas las apariciones de Delarue-Mardrus y otras figuras públicas femeninas en encuestas sobre los temas más diversos, como la participación de las mujeres en los jurados de justicia (Nuevo mundo, 1 de febrero de 1929, en la que se pronuncian, entre otras, las científicas Marie Curie y Anita Bourbonne, la aviadora Marisa Bastié, la abogada Marie Verone y las escritoras Gérard
} 
apasionada, carga contra esa falsa dicotomía y sugiere que así está establecida por la excepcionalidad que todavía es la mujer intelectual dentro del sistema cultural, lo que la conduce a una actitud altiva y pedante y a huir «de lo menudo, de lo íntimo, de lo casero, de lo propio -y por completo independiente de su profesión, de su mucha o poca sabiduría- de su condición de mujer». Esta misma postura es la que sostiene Lucie Delarue-Mardrus, a la que Morales cita para defender, como ella, la necesidad de conciliar esos extremos aparentemente opuestos. En esa misma línea, hará referencia a otra autoridad femenina, Santa Teresa de Jesús, cuya conocida frase «entre los pucheros anda el Señor» le sirve para insistir en la perfecta posibilidad de combinar lo intelectual y lo material, lo abstracto y lo concreto y, en suma, las dicotomías sobre las que, durante mucho tiempo, se ha construido la diferencia de géneros:

Cuando la cultura -ciencia, arte, saber- no sea en la mujer excepción, sino normalidad, quien la posea perderá esos aires de superioridad, de desdén, que tanto se acercan a la pedantería. Sólo entonces llegaremos a la fusión de las dos bíblicas figuras de Marta y de María, que -según la bella imagen de la escritora francesa en este artículo varias veces citada- es, sería, la mujer perfecta, la mujer integral. Sólo así alcanzaremos la serenidad, la elevación que es precisa para vivir -como Santa Teresa quería que viviesen sus monjitas-: con Dios... y con los pucheros a la vez (Morales, 1926: 2).

Morales, por tanto, se adhiere, aunque en versión más austera y castellana, podríamos decir, a ese tenerlo todo que define el imaginario de Delarue-Mardrus y de sus compañeras de Femina y La Vie heureuse. No es de extrañar, dado que ella misma será una de las periodistas españolas que más producción dedique a materias «femeninas» como la moda $;{ }^{9}$ quizás por eso mismo, por habitar en esa contradicción entre el compromiso intelectual y la frivolidad es, de las tres autoras comentadas en esta sección, quien de manera más contundente aprovecha el ejemplo de Delarue-Mardrus para desmantelar el aparato conceptual que sostiene a determinados estereotipos femeninos. En cualquier caso, es evidente que ninguna de las tres -Muñoz, Escoriaza y Morales- se toma los consejos de belleza de Delarue-Mardrus a la ligera: todo lo contrario, esa publicación las lleva a reflexionar sobre qué es ser mujer y sobre cómo conciliar nuevas aspiraciones, de corte emancipatorio, con placeres «femeninos». Que ninguna de ellas entienda estas dos esferas como una antinomia que las distingue radicalmente de sus compañeros, que si bien abordan la publicación de Embellissez-vous! como un punto de parti-

D'Houville y Rachilde entre otras) o sobre los nuevos modelos de masculinidad surgidos después de la Primera Guerra Mundial (Nuevo mundo, 5 de julio de 1929), en la que también participan mujeres de espectáculo como Emilienne d'Alençon, Stacia Napierkowska, Maud Loty y Mistinguet, la pintora Alice Marval y la novelista Raymonde Machard. Más allá de lo pintoresco, estos textos, en los que los retratos de las encuestadas suelen ser profusos, dan pistas sobre cómo se construye la autoridad (auctoritas), concepto tan relacionado con el de autoría.

${ }^{9}$ Lo hace en la revista El hogar y la moda, pero también en sus columnas en prensa generalista como El Sol o La Vanguardia. 
da para pensar sobre la mujer, se muestran mucho más radicales y algo más ingenuos en sus opiniones ${ }^{10}$.

Valgan, a modo de ejemplo, las aportaciones de Cristóbal de Castro en «La escuela de las coquetas» (La Esfera, 1 de julio de 1926) y de Ernesto Pestana en «Feminismo, feminidad y deporte» (La Prensa, 31 de julio de 1926). El primero, constituye una diatriba en toda regla contra Delarue-Mardrus, a la que tilda de «bella desertora» por plantear un retroceso respecto a los avances femeninos conseguidos, puesto que -sostiene el autor- el cuidado del aspecto que la autora propugna no es sino una vuelta a la idea de que la completud de la mujer pasa por tener hogar y marido.

Lucía Delarue Mardrus, la fina poetisa francesa, ha publicado un libro singular. Se titula Embellissez-vous! (¡Embelleceos!), y marca la gran crisis femenina contemporánea. La mujer, conquistando «su puesto al sol», dueña de sí, sid juris, igual al hombre en los destinos y cargos, bastándose a sí misma por el sueldo o el jornal, se encuentra con que no sólo de pan viven el hombre... y la mujer. El entendimiento y el corazón también tienen hambre...

No basta conquistar el cargo y el sueldo, y con ellos la independencia económica. Hay, además, que conquistar el Amor, y con él la independencia y el espíritu. La empleada, la dependienta, la mecanógrafa, la profesora, que viven por sí mismas, tienen casa, pero no hogar. Y la mujer sin el hogar es algo mutilado, interino. «Hogar y mujer se completan», decía Escipión Sighale.

¿Cómo se conquista el hogar? Conquistando al hombre. ¿Y cómo se conquista al hombre? Aquí es donde el libro ¡Embelleceos! Señala rutas sorprendentes (De Castro, 1926: 3).

\footnotetext{
${ }^{10}$ Una panorámica de la postura de las periodistas españolas, incluyendo algunas de las citadas en este artículo, sobre las contradicciones en torno a los nuevos modelos de feminidad puede encontrarse en Pattinson (2017), cuya apreciación de estas permite ver el paralelismo con sus homólogas francesas en los términos expuestos por Mesch (2013: 268): «Algunas periodistas autoras de las páginas femeninas de distintos diarios o revistas ilustradas -María Luz Morales, Carmen de Burgos, Matilde Muñoz o Teresa de Escoriaza- reconocían tanto las nuevas responsabilidades y la dedicación al trabajo como el placer por el ocio y la moda como síntomas positivos del mismo abandono generacional a un tradicionalismo que ofrecía escasa alegría a la mujer española. [...]. Estas periodistas, autoras en momentos distintos de páginas femeninas en periódicos madrileños, celebraban la alegría juvenil y belleza proyectada por la mujer moderna en sus distintas manifestaciones y [sic] intentaban reconciliar su imagen con las visiones que ellas mismas tenían para una sociedad moderna e igualitaria. Para ellas, la nueva generación estará compuesta de mujeres responsables, estudiosas, comprometidas, bellas, divertidas, deportistas, y más independientes que nunca».
} 
Si bien este planteamiento parece mostrarnos una voz que simpatiza con los nuevos derechos y espacios sociales que ha adquirido la mujer, el resto del artículo deja entrever una conceptualización de la cultura que no es ajena a un prejuicio de género evidente. Así, Castro se lamenta de que Delarue-Mardrus haya dimitido del idealismo propio del arte para adentrarse en el terreno de lo banal, una oposición que se sustenta en una conceptualización, la valoración positiva de lo espiritual y lo abstracto y negativa de lo corporal y lo concreto, atravesada por

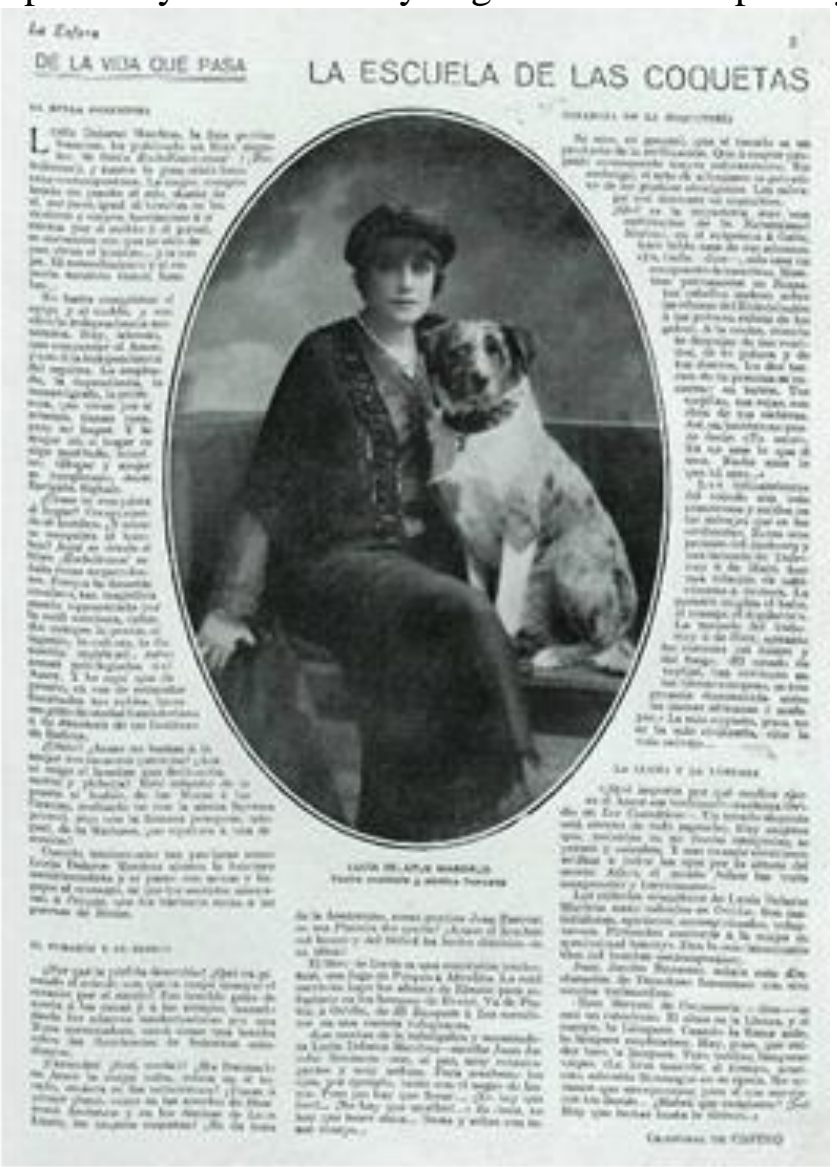

Imagen 4. El retrato de Lucie Delarue-Mardrus realizado por Nadar ilustrando el artículo de Cristóbal de Castro en La Esfera (1926).

Fuente: Biblioteca Nacional de España. el género en la medida en que asocia lo primero con la masculinidad y lo segundo con la feminidad. De ese modo, cuando Castro tilda a los consejos de la autora de «materialistas, epicúreos, antiespirituales, voluptuosos» (además de plagiados de Ovidio) o cuando se lamenta que: «Para sombrear los ojos, por ejemplo, basta con el negro de humo. Pero ¡no hay que llorar!... ¡No hay que leer!... ¡No hay que escribir!... Es decir, no hay que tener alma... Basta $\mathrm{y}$ sobra con tener cuerpo...» no está sino situándose en la misma posición que los moralistas a los que Teresa de Escoriaza se refería

en su columna sobre el tema. De hecho, Castro dedica unos cuantos párrafos del artículo a defender la naturalidad y censurar el adorno del cuerpo, tildándolo de rasgo propio de sociedades incivilizadas, aunque eso sí, el artículo está dominado por una gran y hermosa fotografía que reproduce un original de la serie de retratos de la autora realizada por el famoso Atelier Nadar, bastantes años antes [imagen 4] que incide sobre la corporalidad, la belleza y el adorno ${ }^{11}$.

\footnotetext{
${ }^{11}$ Según la información proporcionada en el catálogo de la BNF, el retrato estaría fechado entre 1900 y 1916, es decir, al menos una década antes de la publicación del artículo.
} 
Por último, es evidente, en especial en esta última cita, que ser culta y ser bella, tener una carrera profesional y tener esposo, etc. se plantean como disyuntiva. Justo la disyuntiva que las cronistas españolas intentan desmantelar en su acercamiento al tema y que la figura misma de la mujer moderna pone en cuestión.

Sin embargo, esta danza entre modelos y contramodelos femeninos resulta compleja, lo que explica reacciones como la de Ernesto Pestana (1926: 1), quien pasa en su columna de opinión de censurar a Delarue-Mardrus por las mismas razones que Castro - «Lucía Delarue Mardrus quiere ahogar los sentimientos femeninos. Nada de las cualidades que han servido para poetizar a la mujer. Ni corazón, ni espiritualidad, ni sensibilidad»- para después alabarla como mal menor frente a otros modelos, a saber, el de la mujer-máquina, personificada en Patrocinio Benito, pionera del automovilismo en España y primera participante en las XII Horas del Guadarrama ese mismo año. Pestana, no cabe duda, ve en esta sportswoman un avance intolerable:

Poco a poco la mujer se ha ido adueñando de los cargos hasta ahora desempeñados por el hombre. La igualdad de derechos sociales no es ya por lo visto, el único fin del feminismo. Aspira también a la igualdad de fuerzas y a la conquista del músculo. Por eso el triunfo de Patrocinio Benito en la carrera de las XII horas aparece como un triunfo del feminismo.

En oposición a estas ideas de la mujer-máquina de trabajo, Lucía Delarue Mardrus, ilustre escritora y poetisa francesa, lanza las páginas delicadas de su libro Embellissez-vous! (Pestana, 1926: 1).

Ante ello, la postura de Delarue-Mardrus le parece más pasable que esta «intromisión femenina en funciones apartadas totalmente de su constitución» que ejemplifica Benito y que el autor argumenta apoyándose en las tesis de Gregorio Marañón en Tres ensayos sobre el problema de la vida sexual (1926-1927):

Trabajo - lucha por la vida - como función eminentemente masculina. Deporte como equivalencia de trabajo: necesidad de practicarlo, cuando el cuerpo del hombre no se emplea en la lucha diaria. Esto es: deporte, trabajo del hombre rico. Y maternidad -perpetuación de la especie-, único fin de la mujer sobre la tierra (Pestana, 1926: 1).

Así, pese a las renuencias que le suscita el libro de la escritora francesa, concluye que su ejemplo es infinitamente mejor que el de la deportista porque: «[...] las recetas de belleza de Lucía Delarue Mardrus -vehículo de sus conceptos- no van a parar sino a la verdadera meta de los designios de la feminidad; cómodo camino hacia la maternidad» para cerrar la columna proclamando: «¿Se llegará a comprender por la mujer el único camino para la emancipación del sexo?». Pocos comentarios caben hacer ante esta pregunta y este artículo en general, salvo constatar la polémica que despierta un tipo de publicación aparentemente 
banal como es un conjunto de consejos prácticos de belleza. Tal polémica solo se puede explicar desde la inquietud que despiertan las transformaciones de la condición femenina en este contexto y que Delarue-Mardrus vehicula tanto en su producción como en su proyección pública. En ese sentido, que diversos intelectuales se interroguen sobre los límites y contradicciones de la mujer moderna a propósito de la autora y que esta adquiera relevancia no tanto o no solo por su obra literaria sino por su diálogo con este nuevo modelo de mujer, resulta un elemento clave de la recepción de Delarue-Mardrus en España.

\section{Conclusión}

El recorrido, necesariamente incompleto, que he realizado a través de la prensa de principios del siglo XX para rastrear la proyección de Lucie DelarueMardrus en España evidencia las particularidades de ser mujer y autora en un momento de debate ardiente sobre la feminidad al hilo de la incorporación imparable de mujeres en la esfera pública del arte y las letras. Aunque encontramos distintas publicaciones centradas exclusivamente en su obra literaria, por ejemplo, los numerosos cuentos que se traducen de manera regular en La correspondencia de España en los primeros años de la década de 1920 o las reseñas y publicidad de algunas de sus obras, su presencia está capitalizada, como he tratado de mostrar por el peso de su figura e imagen pública alrededor de la que orbitan las crónicas más extensas e informadas.

Todas ellas se hacen eco e incluso amplifican una peculiar postura autorial de Delarue-Mardrus que no difiere de la de muchas de sus contemporáneas: una postura que se mueve entre la adopción de estrategias propias de la celebridad y la exhibición de la imagen en unos términos llamativos y la necesidad de reafirmar el valor de la propia obra apelando a elementos tradicionalmente asociados al autor, como la creatividad y la disciplina. Este doble juego en el ámbito de lo mediático y lo introspectivo, lo frívolo y los trascendente se proyecta más allá del desempeño como escritora y alcanza al modelo de mujer que Delarue-Mardrus encarna y/o promociona. Este modelo, que en España se comenta con furor a raíz de sus publicaciones en torno a la belleza femenina, resulta tan contradictorio como su imagen autorial, pero quizás lo más importante es que es percibido como un punto de partida para debatir en la prensa los límites que traspasa o que vulnera la nueva mujer moderna.

\section{REFERENCIAS BIBLIOGRÁFICAS}

Alarcón, Mariano (1923): «Impresiones personales. Mme. Delarue-Mardrus». Elegancias, abril, 18 y 62.

APTER, Emily (1994): «Acting out Orientalism: Sapphic Theatricality in Turn-of-thecentury Paris». L'Esprit Créateur, 34: 2, 102-116.

BerensmeYer, Ingo, Gert Buelens \& Marysa De MoOR (2012). «Authorship as Cultural Performance: New Perspectives in Authorship Studies". ZAA. Zeitschrift für 
Anglistik und Amerikanistik. A Quarterly of Language, Literature and Culture, 60: 1, 5-29.

CAPDEVILA-ARgÜElles, Nuria (2008): Autoras inciertas. Voces olvidadas de nuestro feminismo. Madrid, Horas y horas.

CASTRO, Cristóbal de (1926): «La escuela de las coquetas». La Esfera, 635, 5.

Clayton, Michelle (2012): «Touring History: Tórtola Valencia Between Europe and the Americas». Dance Research Journal, 44 : 1, 29-49.

Collado, Melanie (2003) : Colette, Lucie Delarue-Mardrus, Marcelle Tinayre: émancipation et résignation. Paris, L'Harmattan.

DEWEZ, Nausicaa \& David MARTENS (2009) : « Iconographies de l'écrivain. Du corps de l'auteur au corpus de l'œuvre ». Interférences littéraires, 2, 11-23.

DyHouse, Carol (2010): Glamour: Women, History, Feminism. Londres, Zed Books.

ÉMERY, Elizabeth (2012): Photojournalism and the Origins of the French Writer House Museum (1881-1914). Privacy, Publicity and Personality. Farnham-Burlington, Ashgate.

ÉMERY, Elizabeth (2017): «Methods and Challenges in Deciphering Representations of Authorial Intimacy in Late Nineteenth-Century French Photoreportages», in Masha Belenky, Kathryn Kleppinger \& Anne O’Neil-Henry, French Cultural Studies for the Twenty-First Century. Lanham, University of Delaware Press, 3-20.

ESCORIAZA, Teresa de (1927): «Bajo el régimen rojo». La libertad, 5 de enero, 1.

FAlgairolle, Adolphe de (1927): «Desde París. Crónica de actualidad». Blanco y negro, 1890 (7 de agosto), 19-22.

FELSKI, Rita (1995): The Gender of Modernity. Cambridge, Harvard University Press.

FERRARI Federico \& Jean-Luc NANCY (2005): Iconographie de l'auteur. París, Galilée.

FRANCÉS, José (1911): «Feminismo literario. Escritoras francesas contemporáneas». Por esos mundos, 200, 569-587

GrouT, Holly (2020): "'Le miracle et le mirage': Beauty Institutes and the Making of Modern French Women». Journal of Business History (Special Issue Paper Gender, Feminism and Business History: from Periphery to Centre). DOI: https://doi.org/10.1080/00076791.2020.1820989.

GUNDLE, Stephen (2007): " "Venus on Earth": Lina Cavalieri and the Professionalization of Italian Beauty Between the Fin-de-Siècle and the Belle Époque». Italian Studies, 62: 1, 45-60.

KIRKPATRICK, Susan (2003): Mujer, modernismo y vanguardia en España (1898-1931). Madrid, Cátedra.

GALINDO, Beatriz (1921): «Siluetas del mundo literario francés. Lucie Delarue-Mardrus». La esfera, 372, 4.

GARVAL, Michael (2008): «Cléo de Mérode's Postcard Stardom». Nineteenth-Century Art Worlwide. A Journal on Nineteenth-Century Visual Culture, 7: 1. URL: http://www.19thc-artworldwide.org/spring08/112-cleo-de-merodes-postcardstardom.

GómEZ CARRILlO, Enrique (1923): «El veneno del romanticismo en las poetisas». $A B C$, 6419, 1-2. 
HEINICH, Nathalie (2012) : De la visibilité. Excellence et singularité en régime médiatique. París, Gallimard.

LiNARES, Antonio G. (1924): «El revolver de la gente bien». Nuevo mundo, 1585, 32.

MANGINI, Shirley (2001): Las modernas de Madrid. Las grandes intelectuales españolas de la vanguardia. Barcelona, Península.

MeIzoz, Jêrome (2009): «Ce que l'on fait dire au silence : posture, ethos, image d'auteur». Argumentation et Analyse $d u$ Discours, 3. DOI: https://doi.org/10.4000/aad.667.

MESCH, Rachel (2013): Having It All in the Belle Epoque: How French Women's Magazines Invented the Modern Woman. Stanford, Stanford University Press.

Morales, María Luz (1927): «Páginas femeninas. Dios...y los pucheros». El Sol, 2.767, 2.

MuÑOZ, Matilde (1925): «Lecturas para la mujer. El hogar y la moda». El imparcial, 20.557, 5 .

Newman-Gordon, Pauline (1994): «Lucie Delarue-Mardrus», in Eva Martin Satori \& Dorothy Wynne Zimmerman, French Women Writers. Lincoln y Londres, University of Nebraska Press, 108-120.

NúÑEZ Y TOPETE, Salomé (1908): «Para ellas. Belleza, inteligencia y buen gusto». El liberal, 10.746, 4.

PATTISON, Micaela (2017): «La muchacha moderna: celebridad, sexo y lo privado en público», in Henar Gallego \& Mari Carmen García Herrero (eds.), Autoridad e influencia. Mujeres que hacen historia. Barcelona, Icaria, 263-277.

PESTANA, Eduardo (1926): «Feminismo, feminidad y deporte». La Prensa, 5.152, 1.

RÉVAL, Gabrielle (1924): La chaîne des dames. París, Les Éditions G. Crès et Cie.

RoBerTS, Marie Louise (2002): Disruptive Acts. The New Woman in Fin-de-Siècle France. Chicago y Londres, University of Chicago Press.

Ross Dickinson, Edward (2017): Dancing in the Blood: Modern Dance and European Culture on the Eve of the First World War. Cambridge, Cambridge University Press.

S.A. (1907) : Le Prix «Vie Heureuse ». París, Hachette.

S.A (1920): «Figuras del día». Cosmópolis, 15, 235-244.

SAID, Edward (1979): Orientalism. Nueva York, Vintage Books.

WILSON, Elizabeth (2007): «A Note on Glamour». Fashion Theory, 11: 1, 95-108. 